\title{
Effect of Temperature and Time on Decomposition of $\delta$-ferrite in Austenitic Stainless Steel
}

\section{Vpliv temperature in časa na razpad delta ferita $\mathrm{v}$ avstenitnem nerjavnem jeklu}

\author{
Almaida Gigović-Gekić*, Hasan Avdušinović, Amna Hodžić, Ermina Mandžuka \\ Faculty of Metallurgy and Technology, University of Zenica, Bosnia and Herzegovina \\ * almaida.gigovic-gekic@mtf.unze.ba
}

\begin{abstract}
Microstructure of austenitic stainless steel is primarily monophasic, i.e. austenitic. However, precipitation of the $\delta$-ferrite in the austenite matrix is possible depending on the chemical composition of steel. $\delta$-Ferrite is stable on room temperature but it transforms into $\sigma$-phase, carbides and austenite during heat treatment. In this work, the results of analysis of influence of temperature and time on decomposition of $\delta$-ferrite are presented. Magnetic induction method, microstructure and hardness analyses were used for testing the degree of decomposition of the $\delta$-ferrite. Analysis of results showed that increase in temperature and time increases the degree of decomposition of $\delta$-ferrite.
\end{abstract}

Keywords: austenitic stainless steel, $\delta$-ferrite, $\sigma$-phase, carbides, hardness.

\section{Povzetek}

Mikrostruktura avstenitnega nerjavnega jekla je enofazna, tj. avstenitna. Kljub temu, pa je v odvisnosti od kemijske sestave jekla mogoča tudi prisotnost delta ferita v avstenitni osnovi. Delta ferit, ki je obstojen pri sobni temperaturi, med toplotno obdelavo razpade $\mathrm{v}$ sigma fazo, karbide in avstenit. $V$ tej raziskavi so predstavljeni rezultati vpliva temperature in časa na razpad delta ferita. Za izračun stopnje razpada delta ferita je bila uporabljena magnetna indukcijska metoda in analiza mikrostrukture ter trdote. Analiza rezultatov je pokazala, da se stopnja razpada delta ferita poviša s temperaturo in časom.

Ključne besede: avstenitno nerjavno jeklo, delta ferit, sigma faza, karbidi, trdota. 


\section{Introduction}

Formation of the $\delta$-ferrite is possible by solidifying or welding austenitic stainless steel and it is stable on room temperature. Depending on the chemical composition of the contents of the $\delta$-ferrite stabilising elements such as $\mathrm{Cr}, \mathrm{Si}$, $\mathrm{Ti}, \mathrm{Mo}$, etc., the solidification can start with the crystallisation of austenite or $\delta$-ferrite [1]. Austenitic stainless steel can be solidified in four modes, namely austenite, austenite-ferrite, ferrite-austenite and ferrite. Mode of solidification is very important because it influences the properties of steel, especially mechanical properties and welding ability. Cryogenic toughness and high temperature embrittlement are strongly influenced by the presence of $\delta$-ferrite $[2,3] . \delta$-Ferrite is ductile at room and high temperatures but brittle at cryogenic temperatures. Presence of the $\delta$-ferrite in austenitic $\mathrm{Cr}$-Ni steel and in welded joints increases its strength properties, since grain growth is slowed by the volume-centred cubic crystal structure, and also by the fact that the interfacial boundaries present stronger barriers to the dislocation than the single-phase grain boundaries. However, the $\delta$-ferrite plays a very important role in welding of austenitic stainless steel because it prevents the formation of hot cracks. So it is recommended that up to $10 \%$ of $\delta$-ferrite should be present in weld metal. Also, precipitation of intermetallic phase is increased in the presence of $\delta$-ferrite. Depending on the temperature of the heat treatment, the $\delta$-ferrite can be transformed into $\sigma$-phase, carbides (type $\mathrm{M}_{23} \mathrm{C}_{6}$ ) and austenite [3-7]. With regard to austenite, the $\delta$-ferrite remains a chromium-rich area where diffusion of chromium and other alphagenic elements is faster. Therefore, $\delta$-ferrite is a suitable place for $\sigma$-phase precipitation. The $\sigma$-phase is hard and brittle and it increases the hardness while decreasing the toughness and elongation of the steel. Also, as a result of increasing the content of the s phase, the type of fracture changes from transcrystalline to intercrystalline [8]. During the heat treatment or welding, the occurrence of carbides usually precedes the appearance of intermetallic phases. $\mathrm{M}_{23} \mathrm{C}_{6}$ carbides usually form first at grain boundaries and twin boundaries and then into the austenitic matrix. Car- bides precipitated on grain boundaries particularly make worst the impact properties similar to the corrosion behaviour of austenitic stainless steel $[9,10]$. Due to its very high temperature, it is useful to know the microstructure behaviour of austenitic stainless steel because the mechanical and other properties depend on it. Also, it is possible to have the $\delta$-ferrite in austenitic microstructure, especially during welding, and it is important to study the behaviour of the $\delta$-ferrite at high temperature. The aim of this work is to investigate the influence of temperature and time of annealing on microstructure, especially the $\delta$-ferrite behaviour.

\section{Materials and Methods}

The material used in this study is austenitic stainless steel that was delivered in hot rolled state. The chemical composition of steel is given in Table 1.

$\begin{aligned} & \text { Table 1. Chemical composition of tested austenitic stainless } \\
& \text { steel }\end{aligned}$
\begin{tabular}{ccccccccc} 
Chemical composition, wt./\% \\
C & Si & Mn & Cr & Ni & P & S & N \\
\hline & & & & & & & \\
0.08 & 3.81 & 7.0 & 18.0 & 8.0 & 0.008 & 0.015 & 0.162
\end{tabular}

Specimens for testing were cut from the same bar with diameter of $15 \mathrm{~mm}$. Before testing, all specimens were solution annealed at $1,020^{\circ} \mathrm{C}$ for $60 \mathrm{~min}$ followed by water quenching that brings precipitated carbides and most other intermetallic phases back into solution [4]. Later, the specimens were annealed at $750^{\circ} \mathrm{C}$ and $850^{\circ} \mathrm{C}$ for $5,15,30,60,120$ and 180 min followed by cooling in the air. The microstructural analysis was carried out using the Olympus optical microscope and the scanning electron microscope (SEM) equipped with energy-dispersive spectrometer (EDS). Murakami's reagent $\left(10 \mathrm{~g} \mathrm{~K}_{3} \mathrm{Fe}(\mathrm{CN}), 10 \mathrm{~g} \mathrm{NaOH}\right.$ and $100 \mathrm{~mL}$ $\mathrm{H}_{2} \mathrm{O}$ ) was used for etching. Murakami's reagent at room temperature was used for identifica- 
tion of carbides while heated reagent at $100^{\circ} \mathrm{C}$ was used for identification of the $\delta$-ferrite and $\sigma$-phase. The $\delta$-ferrite content and degree of its decomposition were determined by a Feritscope MP30 (Fisher, Germany). This is the magnetic induction method that takes advantage of fact that the $\delta$-ferrite is magnetic while the austenite, carbides and $\sigma$-phase are not nonmagnetic microconstituents. The average value was calculated on the basis of five measurements (ASTM A800/A800M-91). Hardness test, according to standard BAS EN ISO 6507-1:2018, was performed on specimens prepared for microstructure analysis.

\section{Results and Discussion}

\section{Microstructure Analysis}

The microstructure analysis after solution annealing shows the presence of two-phase microstructure. The microstructure consists of the $\delta$-ferrite in an austenite matrix. The $\delta$-ferrite is elongated in the rolling direction (Figure 1). Etching with Murakami's reagent at high temperature $\left(90^{\circ} \mathrm{C}-100^{\circ} \mathrm{C}\right)$ coloured the $\delta$-ferrite in brown. Also, it can be seen that these stringers of the $\delta$-ferrite are homogeneous.

The results of microstructure analysis of specimens heat treated at $750^{\circ} \mathrm{C}$ and $850^{\circ} \mathrm{C}$ for 5,15 , $30,60,120$ and $180 \mathrm{~min}$ are shown in Figures 2 and 3.

Figures 2 and 3 show the austenitic microstructure with precipitation of secondary phases on the $\delta$-ferrite and austenitic grain boundaries. These figures show the presence of the $\sigma$-phase because Murakami's reagent colours the $\sigma$-phase in blue on high temperature. Presence of the $\sigma$-phase is noticed only on the $\delta$-ferrite. SEM analysis of the tested sample annealed at $750^{\circ} \mathrm{C}$ and $850^{\circ} \mathrm{C}$ confirmed the transformation of $\delta$-ferrite (Figure 4). Analysis confirmed that with increasing temperature and time the form of the $\delta$-ferrite is changed. The form of the $\delta$-ferrite is not more homogeneous and disintegration of the $\delta$-ferrite could be seen. The nucleation of the $\sigma$-phase predominantly occurred at austenite $\delta$-ferrite grain boundaries (Figure 4 ) because grain boundaries and interfaces are the high-energy regions.
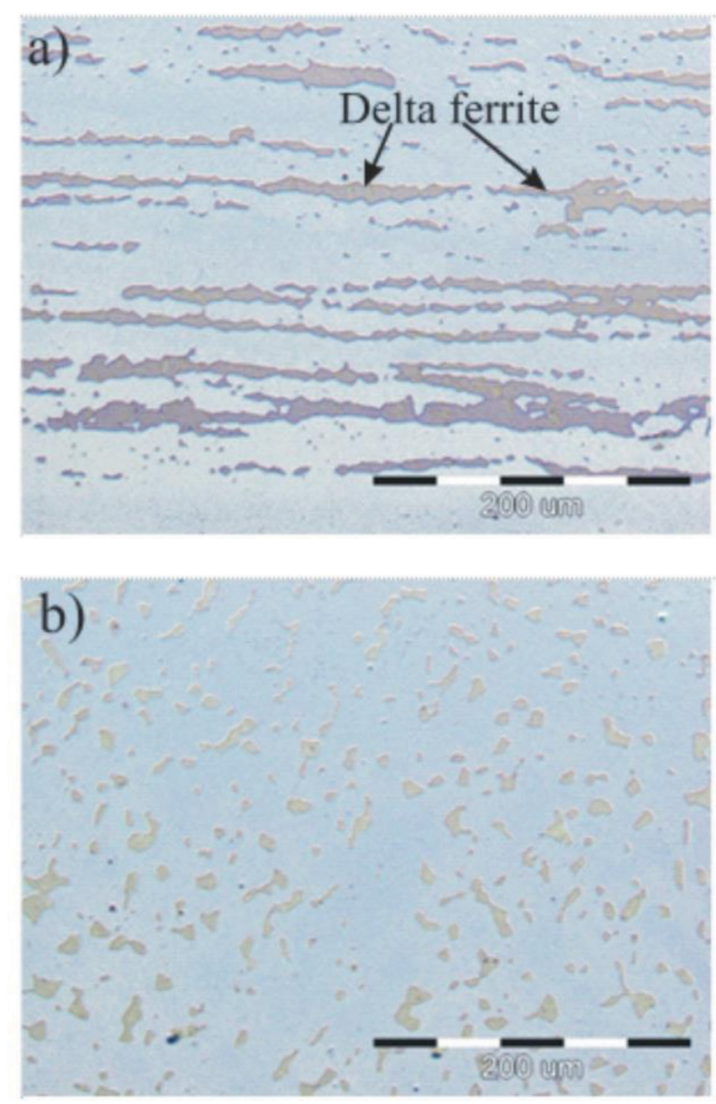

Figure 1. Optical micrographs specimen in solution annealed state: (a) rolling direction and (b) transverse direction, Murakami's reagent (etching at high temperature), 200x.

Table 2. Energy-dispersive spectrometer analysis

\begin{tabular}{ccccc} 
& \multicolumn{4}{c}{ Chemical composition, wt.\% } \\
\cline { 2 - 5 } & $\mathbf{S i}$ & $\mathbf{C r}$ & $\mathbf{F e}$ & $\mathbf{N i}$ \\
\hline Spectrum 1 & 5.01 & 33.27 & 55.65 & 4.1 \\
\hline Spectrum 2 & 4.57 & 26.28 & 60.73 & 6.11 \\
\hline Spectrum 3 & 3.52 & 20.01 & 67.04 & 7.80 \\
\hline Spectrum 4 & 3.57 & 20.35 & 67.92 & 8.16 \\
\hline
\end{tabular}

The average composition of the $\sigma$-phase was determined by EDS analysis and presented in Figure 5 and Table 2 . The results show that the $\sigma$-phase mostly consists of $\mathrm{Cr}$ and $\mathrm{Fe}$. 

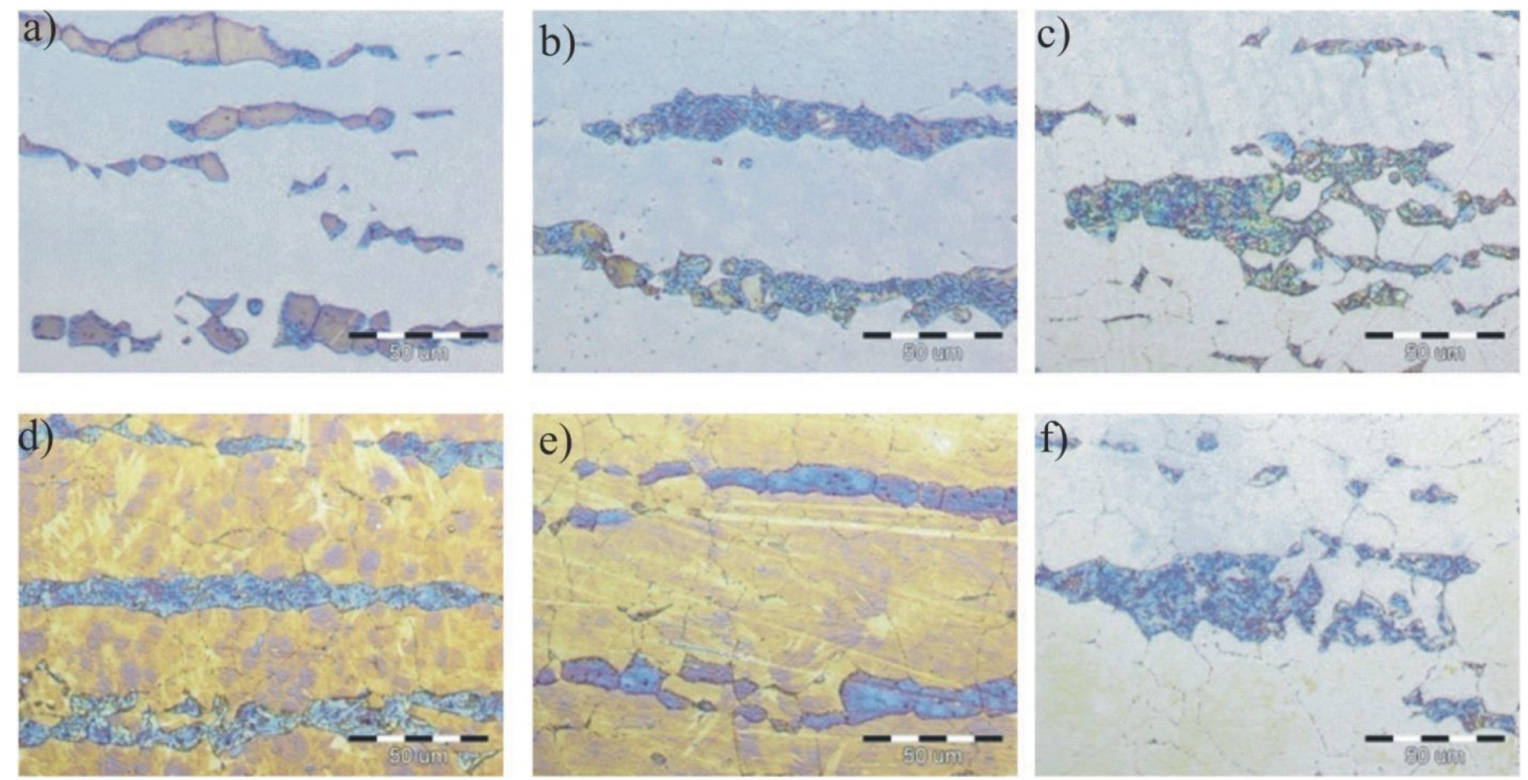

Figure 2. Optical micrographs specimen heat treated at $750^{\circ} \mathrm{C}$ for (a) 5, (b) 15 , (c) 30, (d) 60, (e) 120 and (f) 180 min, Murakami's reagent (etching at high temperature), 500x.
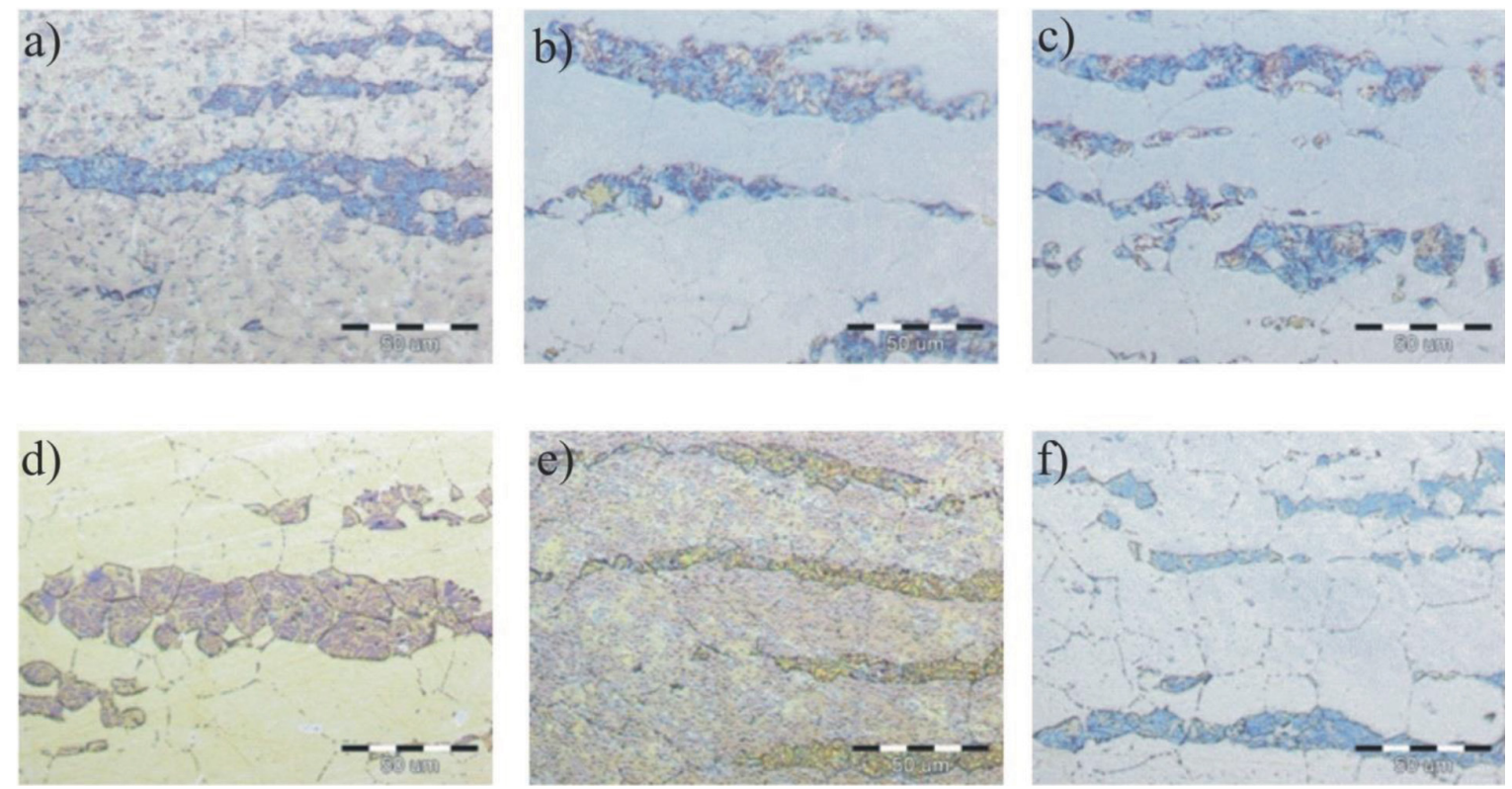

Figure 3. Optical micrographs specimen heat treated at $850^{\circ} \mathrm{C}$ for (a) 5, (b) 15, (c) 30, (d) 60, (e) 120 and (f) 180 min, Murakami's reagent (etching at high temperature), 500x

Although the literature considers the existence of other phases like carbides, analysis by SEM and EDS did not show their presence. To investigate the presence of carbides, etching with Murakami's reagent on room temperature was used. Etching at room temperature, carbides can be revealed at the austenite grain boundar- ies, within the weldment and the $\delta$-ferrite [11]. Figure 6 show the presence of the carbides at austenite $/ \delta$-ferrite grain boundaries and in the $\delta$-ferrite. At temperature $850^{\circ} \mathrm{C}$, carbides were present at austenite grain boundaries too. 


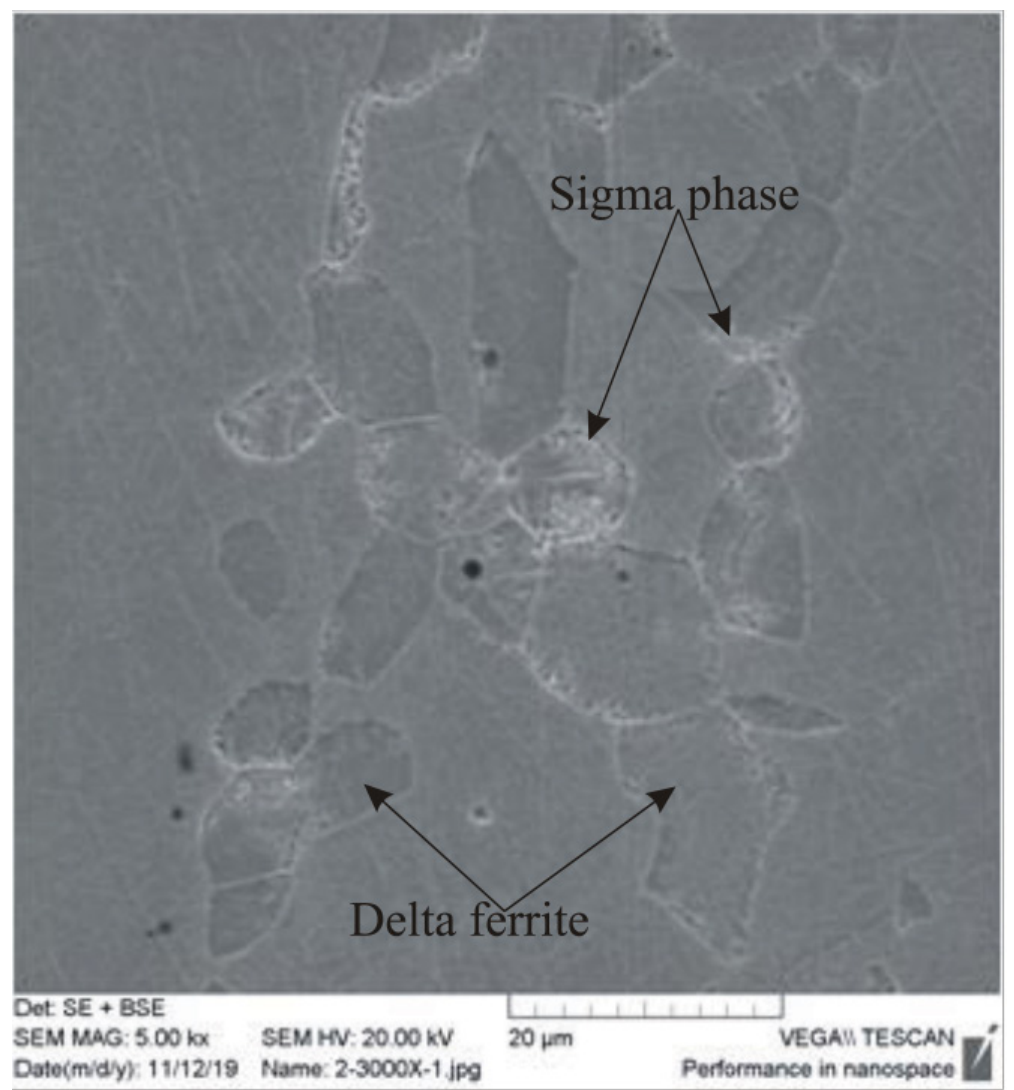

Figure 4. Micrograph of transformation of the $\delta$-ferrite using scanning electron microscope after annealing at $750^{\circ} \mathrm{C}$ for $5 \mathrm{~min}$, $3,000 \times$.

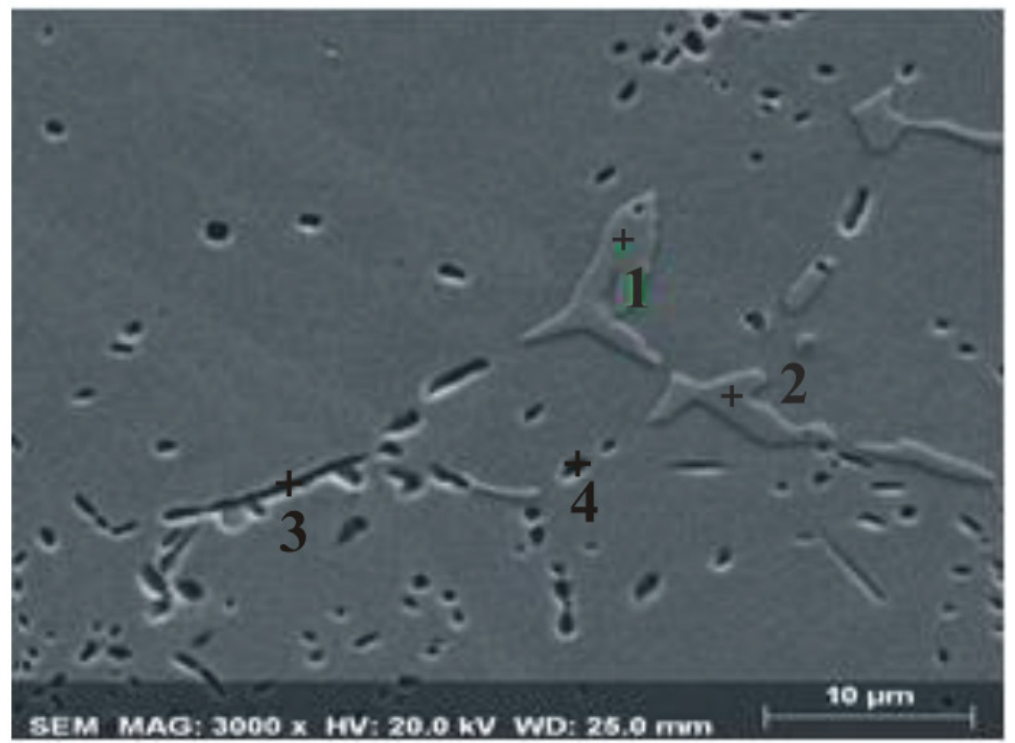

Figure 5. Micrograph of $\sigma$-phase using scanning electron microscope after annealing at $750^{\circ} \mathrm{C}$ for $30 \mathrm{~min}, 3,000 \times$. 

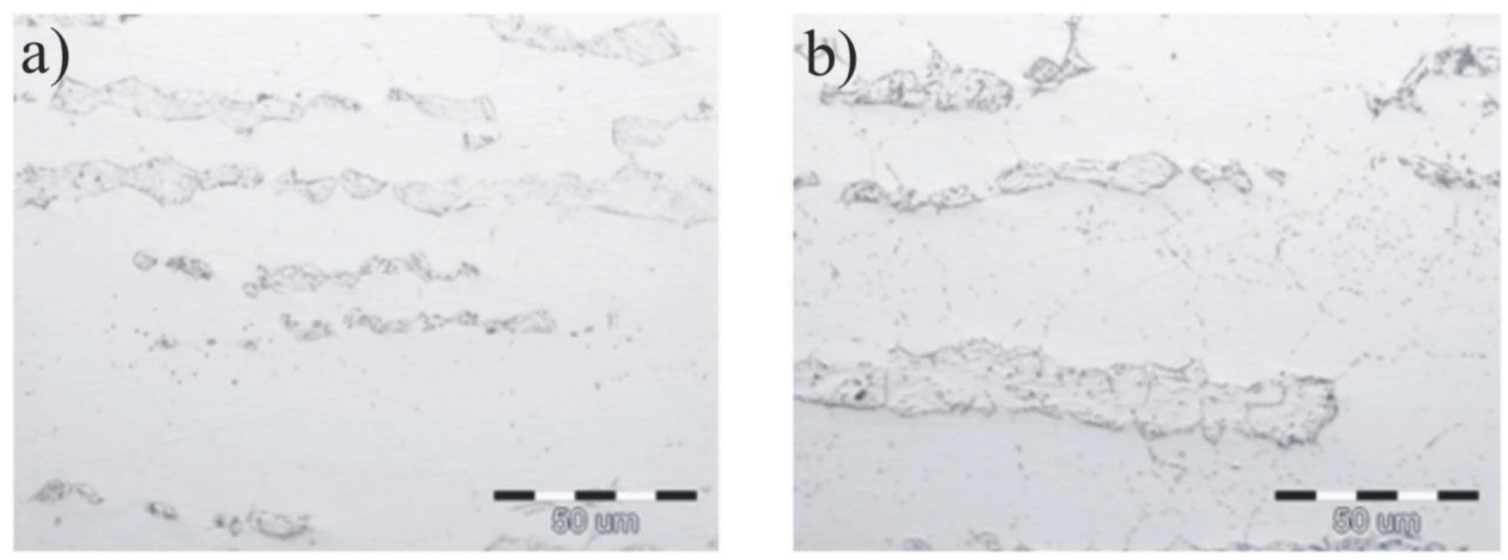

Figure 6. Optical micrographs specimen heat treated: (a) at $750^{\circ} \mathrm{C}$ for $30 \mathrm{~min}$ (cooling in air) and (b) at $850^{\circ} \mathrm{C}$ for $30 \mathrm{~min}$ (cooling in air), Murakami's reagent (etching at room temperature), 500x.

\section{Determination of the $\delta$-ferrite Content}

Feritscope MP30 was used for the determination of the $\delta$-ferrite content. Work of this device is based on the principle of magnetic induction, i.e. the $\delta$-ferrite is magnetic and the austenite, $\sigma$-phase and carbides are nonmagnetic microconstituents. The results of testing are present in Figure 7. The average value of the $\delta$-ferrite in initial solution annealed state was $12.42 \%$.

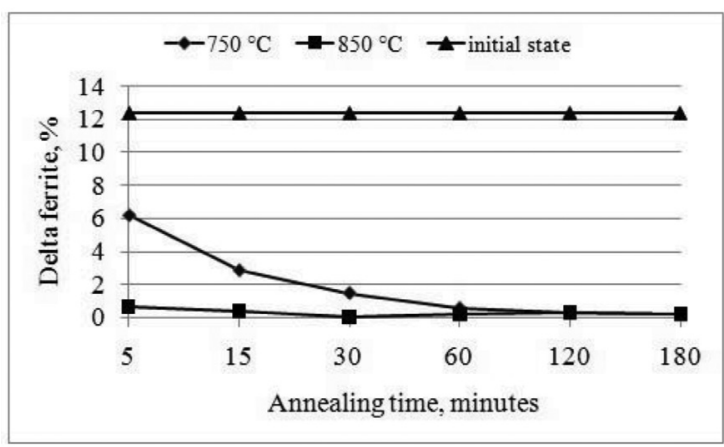

Figure 7. The $\delta$-ferrite content in annealed samples.

Figure 7 shows that with increasing temperature or time the $\delta$-ferrite content decreases compared with an initial state. The time of annealing has strong influence because after $1 \mathrm{~h}$ of annealing the $\delta$-ferrite content is the same for both temperatures.

\section{Hardness Testing}

The hardness was tested on samples prepared for metallographic analysis according to stan- dard BAS EN ISO 6507-1:2018. The samples were taken in the rolling direction. The results of the hardness testing are presented in Figure 8.

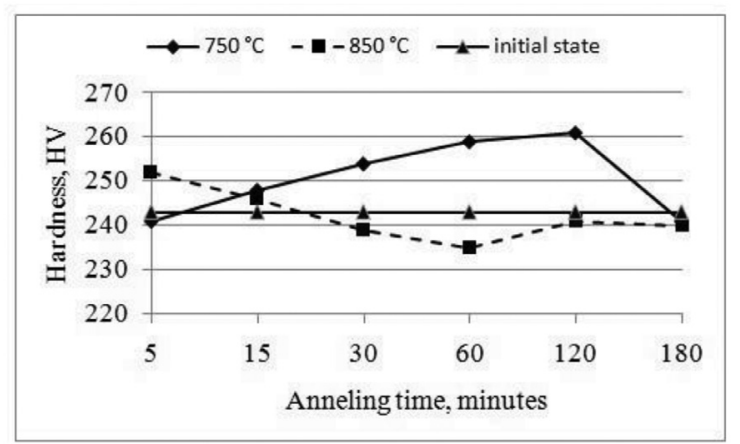

Figure 8. Hardness testing for different temperatures and time.

The testing of hardness showed that with increasing annealing time at $750^{\circ} \mathrm{C}$ hardness increases to $120 \mathrm{~min}$, and later hardness decreases on the hardness of initial state. Hardness decreases with increasing annealing time at $850^{\circ} \mathrm{C}$, but after $1 \mathrm{~h}$ hardness increases on the hardness of initial state. Influence of temperature on hardness was the opposite. After 5 min of annealing, the highest decomposition of the $\delta$-ferrite was at $850^{\circ} \mathrm{C}$ (about $95 \%$, almost two times more than at $750^{\circ} \mathrm{C}$ ) and for those samples the hardness was the highest. However, the hardness decreases with increasing annealing time to $1 \mathrm{~h}$. Then the hardness increases 
to the initial state hardness. In case of annealing at $750^{\circ} \mathrm{C}$, the situation is opposite, i.e. the hardness increases to $2 \mathrm{~h}$ of annealing than it decreases to the initial state hardness. After $3 \mathrm{~h}$ of annealing, the hardness is the same for both temperatures and it is almost the same as the initial state hardness.

\section{Conclusions}

From the results of investigation of influence of temperature and time on microstructure of austenitic stainless steel, i.e. decomposition of the $\delta$-ferrite the following could be concluded:

- Initial microstructure of steel after solution annealing is austenitic with average value of $12.42 \%$ of the $\delta$-ferrite.

- Increase in temperature and time of annealing resulted in decomposition of the $\delta$-ferrite. After $30 \mathrm{~min}$ of annealing, content of the $\delta$-ferrite was reduced to less than $2 \%$, i.e. about $90 \%$ the $\delta$-ferrite was transformed.

- Influence of temperature on decomposition of the $\delta$-ferrite decreases with time because after $1 \mathrm{~h}$ annealing the ratio of decomposed $\delta$-ferrite was the same for both temperatures. Temperature and time are very important for a diffusion process. It is possible to get the same results for higher temperature and shorter time or vice versa.

- Etching with Murakami's reagent on room temperature showed the presence of the carbides. Precipitation of the carbides was the first on austenite $/ \delta$-ferrite grain boundaries and in the $\delta$-ferrite. With increasing temperature and time, the carbides were precipitated on austenitic grain boundaries too.

- After $180 \mathrm{~min}$, hardness of annealed samples at $750^{\circ} \mathrm{C}$ and $850^{\circ} \mathrm{C}$ is almost the same as the initial state.

\section{References}

[1] Tehovnik, F., Vodopivec, F., Kosec, L., Godec, M. (2006): Hot ductility of austenite stainless steel with a solidification structure. Materiali in tehnologije, 40(4), pp. 129-138.

[2] Koseki, T., Inoue, H., Morimoto, H., Ohkita S. (1995): Prediction of Solidification and Phase Transformation of Stainless Steel Weld Metals, Report No. 65, Nippon Steel Technical.

[3] Kožuh, S., Pavičić, K., Ivanić, I., Bizjak, M., Gojić, M. (2019): The effect of Annealing Time on Microstructure and Impact Energy of Stainless Steel AISI 316L. In: Proceedings of $18^{\text {th }}$ International Foundrymen Conference, Coexistence of material science and sustainable technology in economic growth, Sisak, Croatia, Dolić, N., Zovko-Brodarac, Z., Begić-Hadžipašić, A. (eds.). University of Zagreb, Faculty of Metallurgy: Sisak, pp. 275-287.

[4] Barcik, J. (1988): Mechanism of $\sigma$-phase precipitation in $\mathrm{Cr}-\mathrm{Ni}$ austenitic steels. Materials Science and Technology, 4(1), pp. 5-15, doi.org/10.1179/ mst.1988.4.1.5.

[5] Folkhard, E. (1988): Welding Metallurgy of Stainless Steels. Springer-Verlag: Wien, $279 \mathrm{p}$.

[6] Yushchenko, K.A., Savchenko, V.S., Solokha, A.M., Voronin, S.A., (1993): Effect of Delta-Ferrite on the Properties of Welds in Austenitic Steels at Cryogenic Temperatures. Advances in Cryogenic Engineering Materials, 40(A), pp. 1263-1266.

[7] Astaf'ev, A.A., Lepekhina, L.I., Batieva N.M. (1989): Effect of delta-ferrite on the properties of welded joints of steel 08Kh18N10T. Metal Science and Heat Treatment, (31), pp. 880-884.

[8] Llorca-Isern, N., López-Luque, H., López-Jiménez, I., Biezma, M. V. (2016): Identification of sigma and chi phases in duplex stainless steels. Materials Characterization, (112), pp. 20-29, doi.org/10.1016/j. matchar.2015.12.004.

[9] Padilha, A.F., Rios, P.R. (2002): Decomposition of Austenite in Austenitic Stainless Steels. ISIJ International, 42(4), pp. 325-337, https://doi.org/10.2355/ isijinternational.42.325.

[10] Khatak, H.S., Raj, B. (2002): Corrosion of Austenitic Stainless Steels: Mechanism, Mitigation and Monitoring. Narosa Publishing House: New Delhi, 385 p.

[11] Identification of Phases in Stainless Steels by Etching. G.V. Voort, [cited 30/01/2019], Available on: https://vacaero.com/information-resources/metallography-with-george-vander-voort/1061-identification-of-phases-in-stainless-steels-by-etching.html. 